\title{
An atypical differentiation: Vaslui vs Vasluieț ${ }^{\dagger}$
}

\author{
Vlad Cojocaru* \\ "A. Philippide" Institute of Romanian Philology, Str. Th. Codrescu 2, 700481 Iași, Romania
}

\section{Article info}

History:

Received July 4, 2018

Accepted July 20, 2018

Published October 7, 2018

Key words:

toponymic field

hydronymic differentiation

toponymic extension

diminutive

tributary watercourse

\begin{abstract}
This research aims at offering an explanation to a toponymic microstructure, analysing to what extent this can be classified in a type already discussed in some works of specialty under the name of hydronymic differentiation. Neutralization of an opposition created at the name level between a watercourse and its main tributary, as a result of a process of hydronymic extension, is marked at the denominative level through the substitution of the basic form of the hydronym by its diminutive form. In order to monitor a possible evolution of the relationship of designation, diverse sources have been used, relevant for an analysis of the names both at popular level and official one, noted in written documents or recorded in the field through direct inquiries. The attestations lead to the conclusion that we do have a hydronymic differentiation, at least at a certain level, but in this case we don't have an extension of the name of the main tributary over the confluent watercourse.
\end{abstract}

\section{Introduction}

The City of Vaslui situated on Vasluieț River: is this an illustration of the type Corod on Corozel, Tecuci on Tecucel, consequently admitting a similar explanation? In the case of the village called Corodul the disappearance of the old name of the brook, on which this is located and from which it took its name, has been explained by Dragoș Moldovanu:

"Frequently the toponymic extensions affect the hydronyms. Thus a primary opposition between Corod (a tributary of the Bîrlad River) and Corozel (the right main tributary of Corod) has been neutralized by an extension of the denotatum Corozel in two stages: firstly, onto the inferior course of Corod, downstream the junction with Corozelul, and then over the superior course of Corod, before this junction. The hydronym Corod has completely disappeared and a new differentiation, by the waterflow, is created between the main course of Corozel (previously named Corod, and now Corozelul cu Apă 'Corozel with Water') and its right tributary (previously named Corozel, and now Corozelul Sec 'Dry Corozel'). It is likely that this double extension was enhanced (if not even triggered somehow) by the relative homonymy of the hydronym with the oikonym Corod, designating the riverside village."

(Moldovanu, 2014, p. XII; our translation)

The linguist of Iași includes in the same category of hydronymic extensions also similar processes from other two toponymic fields, in the absence of an individualized analysis for each case, as the last two toponyms mentioned below are not treated in MDTM, I, tome which contains only toponyms on anthroponymic base:

"Same evolution can be noticed also in other hydronymic fields (Tecuciul and Tecucelul, Vasluiul and Vasluiețul), having as a result the creation of a new privative opposition, between the hydronym (in its diminutival form) and the oikonym (the towns Tecuci and Vaslui)."

(Moldovanu, 2014, p. XII; our translation)

†This paper was presented at the symposium “Toponymy between history, geography and linguistics”, Iași, May $10^{\text {th }}, 2018$.

*Email address:vldcojocaru@yahoo.com. 
Vlad Cojocaru

In order to use the same reasoning for the pair Vaslui / Vasluieț, we should identify within the hydrographical network of the river Vaslui a main tributary designated with the diminutival form of the hydronym. More specifically, aiming at reconstructing the normal relationship between the two components of the field, namely the oikonym Vaslui and the hydronym Vasluiet, would require the identification of the secondary watercourse designated by the diminutival form of the toponym, which was the source for the process of extension of the tributary name onto the main watercourse.

1.1. In Dimitrie Cantemir's Descriptio Moldavize we actually find the two forms of the hydronym, Vasluiul together with Vasluiețul, denominating apparently different designata, both having the quality of tributaries of the Bîrlad River, at least in author's opinion (apud Ghibănescu, XV, p. 128 ${ }^{1}$ ). After examining the names of the tributaries along the entire course of the river, we couldn't find the denomination assigned to anyone of them, neither in its primary form, nor in its diminutive one, except for the springs area. However, it is difficult to admit the possibility of a hydronymic extension started from this area. Neither the configuration of the hydronymic network of the river Vaslui helped us identify an eventual main tributary to be at the origin of the process of toponymic extension, similar to the case of Corod field.

\section{The hydronym Vaslui in different sources}

In order to provide an explanation for the change of the relationship between the components of the mentioned toponymic field ${ }^{2}$ we analysed the evolution in time of the names used to designate the river on which the present city of Vaslui is situated.

\subsection{Edited documents}

Firstly we tried to track, in the documents edited in DRH, A collection, the attestations for the hydronym designating the river on which the Vaslui Town was situated, as well as a possible documentation of its diminutival form. The occurrences of the hydronym have been noted all along the rivercourse, inferior, middle or superior, in a chronological order, starting from the most ancient to the most recent.

The year 1429: the hydronym is attested in its primary form in a donation deed belonging to Alexandru cel Bun, who is giving the Lord Bena "a village on Vaslui, one half of Făurei" (I, p. 141).

The year 1438: Voivodes Ilie and Ștefan confirm to the Lord Oană Portariul "the villages, on Vaslui, namely Brudureștii [...] and Seliștea of Fundea” (I, p. 268, Slavic original).

The year 1443: Voivode Ștefan confirms to the Lord Moica and Lord Tudor several villages, among them also some "on Vaslui" (I, p. 340, Slavic original).

The year 1472: Ștefan the Great confirms to Cristea Negoiu the villages "Negoieștii [...] and Ungurenii, and the watermill on Vaslui in front of Ungureni" (II, p. 264, copy from 1835).

The year 1487: the village Cîrjanii "on Sărata ${ }^{6}$, the part towards Vaslui" (III, p. 17, Slavic original).

The year 1491: S,tefan the Great buys "two villages on Vaslui upstream of the Town of Vaslui, namely Brudureștii [...] and the village Mărățăi, on Vaslui [...] former Părtănoși” (III, p. 189, ancient translation). From the same document we cite some more relevant details found in the deed of the village confines: "then it crosses Vaslui at the Mound carved in the bank of the river Vaslui" (III, p. 191).

\footnotetext{
${ }^{1}$ This information does not appear in Cantemir's maps, cf. TTRM, $\mathrm{I}_{4}$, s.v., where we find only Vasluy Fl. and Waslui Fl.

${ }^{2}$ For the concept of 'toponymic field', see Moldovanu (2010, p. 16-20).

3 *Făurei, village on Vaslui <near Benești, commune Tanacu, district Vaslui〉; downstream of Moara Domnească.

${ }^{4}$ Brudureștii <today Portari, commune Zăpodeni, district Vaslui〉; Seliştea lui Fundea, on Vaslui near Portari〉.

${ }^{5}$ Ungureni <above Solești (?), commune Solești, district Vaslui>; the middle coure of Vaslui.

${ }^{6}$ Right tributary of the river Vaslui, at the village Moara Domnească 'Royal Mill'.
} 
The $16^{\text {th }}$ century: the hydronym is documented further more in its primary form within the confines of some villages near Șerbotești ${ }^{7}$, in the description of these confines being noted "the road of Stan Preutescu through Vaslui water and therefrom along the stream of Vaslui downwards, until Brebi" (I, p. 418, document forged in the $16^{\text {th }}$ century).

The year 1502: "the granddaughter of Toma Solescu sells a village on Vaslui, namely Solești" (III, p. 482).

The year 1503: five villages are sold on Dobrovăț "at the sources of Dobrovăț and Pietroasa, up to the origin of Vaslui, at a linden tree [...] close to the road that goes from Buciumi to the Monastery of Dobrovăț [...] at the riverbed of Vaslui, along the riverbed of Vaslui downstream onto the mouth of Dobrovăț, where Dobrovăț falls into Vaslui” (III, p. 527).

The year 1623: "from the Hill of Vaslui [...] it crosses the brook Sărata and reach the Glod 'Muddy Brook"”' (XVIII, p. 21, Slavic original).

The year 1623: an estate is sold in the village "Strîmtură [...] including a place for a watermill which is on the river Vaslui" ${ }^{10}$ (XVIII, p. 25, Slavic original).

The year 1624: a part of Miclești "including a place for watermills in Vaslui". In the same document it is mentioned "a part of the glade from Cîrnul, also with a place for a watermill in Vaslui" 11 (XVIII, p. 284).

The year 1625: “The priest Gonțea of Solești together with his people for a mill made by them all in the water of Vaslui" (XVIII, p. 324, Romanian original).

The year 1625: it is mentioned the village of Dușești "with two mills in Vaslui" and in the same document in a clearer formulation, "the village Dușaşsti ${ }^{12}[\ldots]$ with two mills in the brook of Vaslui” (XVIII, p. 453, copy from 1835).

The year 1628: Miron Barnovschi Moghilă donates to the church from the town of Vaslui "some mills on the stream of Vaslui" (XIX, p. 531).

The year 1639: a transaction in the villages Nourești and Poiana Cîrnului "with a mill ford on the stream of Vaslui" ${ }^{13}$ (XXV, p. 200, Romanian original).

The year 1640: part of Miclești "that is named Berindieștii, which is in the district of Vaslui, on the river Vaslui" (XXV, p. 426, Slavic original).

The year 1643: the village Popeștii "at the beginning of the River Vaslui [...] this village, Popeștii, from the springs of the River Vaslui [...] with a mill and with the monastery of Trestiiana" ${ }^{14}$ (XXV, p. 142, copy from 1825).

The year 1644: "the village Rusenii with half the mill ford that is on the River Vaslui" 15 (XXVII, p. 429, Slavic original).

\footnotetext{
${ }^{7}$ Șerbotești, a village on the middle course of Vaslui River.

${ }^{8}$ Brebi, place < at Popești, commune Miclești, district Vaslui>.

${ }^{9}$ The Hill of Vaslui within the confines of the village Prigorceni, district Vaslui, on Sărata Brook; the name of the hill comes from the name of the town. For Glod, cf. the brook Glodul, right tributary of Vaslui, near the village Solești.

${ }^{10}$ Near Șchei, Ferești, on the brook Sărata.

${ }^{11}$ Poiana Cîrnului 'The Glade of Cîrnul', currently Poiana, commune Schitul Duca, a village on the superior course of the river Vaslui.

${ }^{12}$ Ex-village on Vaslui <probably near Codăiești and Movila lui Burcel>.

${ }^{13}$ On the superior course of Vaslui.

${ }^{14+}$ Popeștii, former village near Pocreaca, commune Schitul Duca, Iași County; ${ }^{+}$Trestiana, former village (and monastery), West of the village Poiana, commune Schitul Duca.

$15 *$ Rusenii, former village on Vaslui <near Mircești, commune Tăcuta, Vaslui County>.
} 
The year 1644: the village Totoieștii "with a mill ford on the River Vaslui" ${ }^{16}$ (XXVII, p. 385, Slavic original).

The year 1678: "a deserted village namely Strahoeștii on the stream of Vaslui upwards of the town in the district of Vaslui" (Ghibănescu, VIII, p. 254, Slavic document).

The year 1686: "Șerbești [...] with the mill ford on the stream of Vaslui"17 (Ghibănescu, V, p. 330).

The year 1704: Mihai Racoviță donates to Panaite pîrcălabul 'the Warden' “a mill ford in the water of Vaslui in front of the town" (Ghibănescu, XV, p. 124).

The year 1796: The superior of the Monastery Dobrovăt gives in exchange to the hatman C. Ghica "a mill ford on the stream of Vaslui at the town of Vaslui" (Ghibănescu, XV, p. 184). The exchange is confirmed in 1805 by C. Moruz, using the same terms: "a mill ford on the stream of Vaslui at the town of Vaslui" (p. 212).

According to the series of attestations proved above, the primary form of the hydronym seems to be the only name used in documents, starting from the $15^{\text {th }}$ century up to 1800 , to designate the river which flows close to the city of Vaslui and goes into Bîrlad River below the city.

\subsection{Cartographical documents and geographical works}

The study of the geographical sources appears to bring some extra-information, at least about the composition of the field of the hydronym Vaslui, if not about its diminutive competing the basic form.

2.2.1. Thus in ATLAS MOLD. from the end of the $19^{\text {th }}$ century the following forms are documented:

a. The Brook Vasluiu, at Schitul Ducăi, Poiana Cîrnului and downstream, at Pribești, Deleni;

b. The Brook Vaslueț, the final left branch of the River Vaslui, North of the village Poieni, but also the final right branch of the River Vaslui, South of the village Poieni;

c. The Plain of Vaslui, between the villages Solești and Șerbotești, North of the city of Vaslui, on the River Vaslui, upstream the villages Moara Grecilor and Moara Domneascăă ${ }^{18}$.

The documentation of the diminutival form for the designation of a tributary in the springs area of a river, or of its final branches, is absolutely normal, one could say even a 'common thing' within a toponymic field developed around a hydronym.

2.2.2. Geographical works from the second half of the $20^{\text {th }}$ century confirm the supplementary information about the composition of the analysed field, provided by the Atlas from 1895, with a contribution regarding the inferior course of Vaslui.

ROM.: Vaslui, river.

HARTA MIL. from 1962:

a. Vaslui, river, bearing this name upstream upto the villages Poieni and Schitul Duca;

b. Vasluiet, the left final branch of Vaslui, which flows into this one at the village Poieni;

c. Vasluiet, the inferior (?) course of the river Vaslui, downstream the city of Vaslui, until its junction with the River Bîrlad.

TTRM, I $\mathrm{I}_{4}$, s.v. Vasluiul: major left tributary of the River Bîrlad (in the city of Vaslui, metropolis Vaslui, district Vaslui) - starting from Dimitrie Cantemir's map from the year 1716 until Bawr's map from 1781 .

TTRM, I $\mathrm{I}_{3}$, s.v. Vasluiul: Left tributary of the River Bîrlad.

\footnotetext{
$16 *$ Totoieștii, former village on Vaslui <near Burcelu, included in Codăiești> .

${ }^{17}$ East of Codăiești.

${ }^{18}$ The use of the hydronym Vaslui attested indirectly also for this section of the river.
} 
Gugiuman (1988, p. 313): Vaslui, brook of $64 \mathrm{~km}$, left tributary of the river Bîrlad, at the SE limits of the metropolis Vaslui.

Therefore in documents and cartographical sources, and at the geographers as well it is documented the name Vaslui for the main watercourse, the diminutival form being sometimes used for the designation of a final branch from the springs area. In one of these sources, the diminutival form of the name is also used to designate the mouth area of the brook, near the homonymous city.

\subsection{The hydronym Vaslui / Vasluieț in modern sources}

In modern sources (which consign originally oral forms) it is documented, unexpectedly, the extended use of the hydronym Vasluietul for the designation of the entire main watercourse, from the springs downwards to the mouth of the river, by total replacement of the old denomination.

2.3.1. The first total turn in the denominative perspective is surprisingly provided by a work which is contemporary with ATLAS MOLD., which was still preserving the initial form of the hydronym (see supra). This is MDG, where the river in discussion is called in different tomes of this work uniquely with the diminutival form of the hydronym.

The Brook Dobrovățul, which originates in Bîrnova Hill, "flows into the brook Cuțigna ${ }^{19}$ and then together into Vaslueț"20 (III, p. 158/2).

The River Bîrlad passes through the communes Rădiul and Vasluiul "where it gets the brook Racova on the right and Vasluiețul on the left"21 (V, p. 722/3).

"Valleys with brooks, which gradually end on one side of the brook Vasluețul, namely: Valea Șerbești, Valea Ferești, Olănești”22 (V, p. 722/1).

In a fragment which presents the orography of the district of Vaslui: "the ridge that goes between the brooks Vasluiețul and Dobrovățul [...] and Codăești, where there is exactly the junction of these two brooks"23. Another ridge, which goes parallel to the Brook Vasluieț "ends at the junction of Vasluieț with the river Bîrlad [where] exactly the city of Vaslui is situated"24 (V, p. $722 / 1)$.

The urban commune of Vaslui is "situated at the Southern end of the Hill Delea within the angle formed by the junction of the brook Vaslueț with the river Bîrlad. [...] On the Eastern side [of the city of Vaslui] opens the wide valley of Crasna, with the brook Vasluet flowing through and which, downwards the city, is throwing into the water of Bîrlad" (V, p. 723/2).

"Sărata, the brook [that flows through] the commune of Ferești and [...] the commune of Dănești [...] crosses the territory of the village Moara Domnească [...] flows into the brook Vaslueț” ${ }^{25}$ (V, p. 338/2).

2.3.2. The new denominative perspective is confirmed by other sources, which are (also) based on oral and local information.

\footnotetext{
${ }^{19}$ In HARTA MIL. it is named Rediul in its inferior course.

${ }^{20}$ For the year 1503 DRH, A, III was offering an occurrence with the Brook Dobrovățul being the tributary of a river named Vaslui: "where Dobrovățul falls into Vaslui", see supra.

${ }^{21}$ Thence the tributary of the River Bîrlad in front of the city of Vaslui is not River Vaslui, but Vasluieț.

${ }^{22}$ The Brooks Șerbești, Ferești, Olănești are the tributaries of the river Vaslui, see the map.

${ }^{23}$ At Codăiești there is the junction of the brook Dobrovățul with Vasluiul, therefore Vasluiețul from the cited fragment stands for the originary hydronym.

${ }^{24}$ See note 21 .

${ }^{25}$ See supra the attestation from 1487: the village Cîrjanii „on Sărata, the part towards Vaslui”, which shows that the cited brook was designating a tributary of Vaslui.
} 
The River Vasluieț, a tributary of Bîrlad, is the main watercourse in the village Muntenii de Sus, district of Vaslui (NALR-DATE, p. 298).

For the clerks of the Town Hall of the commune of Schitul Duca, district of Iași, the hydrographical network is "formed by surface waters, namely Slobozia and Vasluieț, with its tributaries Tabăra, Pocreaca and Vasluieț" 26 (primariaschituduca.ro).

On the map of the village Dumitreștii Gălăţii, the river Vaslui is named Vasluieț, this denomination being kept until its flowing into the River Bîrlad, near the mouth of the river Crasna upstream. Alongside the city of Vaslui there is no differentiation between a presumable new course of the river Vaslui, beneath the town, and the old course, eastwards (that is Vasluiul Vechi or Vasluiețl [Vechi]). The river seems to include also the watercourse named Vasluieț in the military map and in Atlasul rutier, where it is (?) marked the distinction between the river Vaslui (the main watercourse) and Vasluiet, from the inferior course of the river. (dumitrestiigalatii-is.pe-harta.ro).

The online map on Google site exhibits the same situation as the other maps from the sites of different villages, with the use of the diminutival form of the hydronym to designate the river named only Vaslui in historical documents and geographical works (google.com/maps).

\section{Evolution of the relationship of designation in the case of the hydronym Vaslui}

Commenting on the information offered by the sources discussed above, one can notice that the old documents and the genuine cartographical sources exhibit the normal situation of the discussed toponymic field, namely the hydronym Vaslui, along with its diminutival derivative Vasluieț designating the left constituent branch of the river Vaslui, besides some cartographical sources have also the hydronym Vasluieț designating this time the inferior course of the main river or at least a diverted branch of this one in its inferior course. The initial denomination of the river appears from the oldest documents and it is preserved for the designation of the main watercourse, on which the homonymous town was in fact situated, until the end of the $18^{\text {th }}$ century. This situation is confirmed and continued up to present also by the authentical cartographical sources invariably.

3.1. The situation seems to change completely starting from the modern sources providing in fact information collected in the field, which is intriguing most of all: in these sources, starting from the end of the $19^{\text {th }}$ century, the initial name of the river is replaced by its diminutival form, which until then was used to designate either a tributary from the springs area, or a diverted branch of the main course in the mouth area.

Accordingly, we found the confirmation of the circulation of the hydronym in its diminutival form for the designation of the main watercourse in NALR-DATE, p. 298, where the inhabitants of the village Muntenii de Sus identify the river crossing their territory by the name Vasluiet, and not Vaslui, being qualified as the main tributary of the River Bîrlad. The same situation is documented, as we previously stated, since 1900, when the city of Vaslui is said to lie „in the angle formed by the junction of the brook Vasluețl [and not Vaslui] with the river Bîrlad” (MDG, V, s.v.), without mentioning at all the river Vaslui, as we would expect. In the same source we find a supplementary attestation of this odd situation:

"Eastwards the broad valley of Crasna opens, with the brook Vasluet flowing through, which, downstream the city, is throwing itself into the water of Birlad."

\footnotetext{
${ }^{26}$ Here shows up the homonymy, not troublesome for the authors of the site, between the name of the main watercourse Vasluieț and its tributary from the springs area, named also Vasluieț. In other words, Vasluieț flows into Vasluieț.
} 
Therefore Vasluieț wouldn't be a tributary of a river named Vaslui, which is normal, but of any other watercourse, no matter the name (in our case, Bîrlad), provided it is not Vaslui. If in the case of Corozel, proved to be not a tributary of a brook called Corod, but the tributary of Bîrlad River, as well as the brook Tecucel, an explanation could be found for this apparently odd situation, in the case of Vasluieț, as aforesaid, one cannot use the same kind of explanation.

3.2. The first historical document offering in the structure of the toponymic field the diminutival form of the hydronym seems to be from the year 1783, document that consigns a dispute between the Monastery Dobrovăț (and its subsidiary, Monastery Lipovăț near Vaslui) and the scribe Clement for a mill ford in the watercourse of Vaslui in the town area. Clement invokes a document he possesed and that was emitted by Mihai Racoviță in the year 1705 for a mill ford in the water of Vaslui close to the town, claiming that the monastery steals the water from his mill, despite the fact that this didn't have any right in this place, if not in the Old Vaslueț (Ghibănescu, XV, p. 156). This phrase, redundant from the point of vue of the marks of differentiation from the basic toponym, that is combining the suffixe mark with the adjectival determination, is getting clearer through the inquiry commanded by the voivode in order to cease the conflict. Has the Monastery Lipovăț any right to make a mill in the New Vaslui, where Clement made his mill, or in the water of the Old Vasluiet, as the last claims? The inhabitants of Vaslui Town do not know the answer, or as the document consigns "nobody was found to know either about the watercourse of Vaslui since when it was diverted, or when the New Vaslui was made, the others don't know except for one Ion Iftodi [who] would have heard that during the days of Ștefan the Great the Old Vaslui had been moved and the new one was made" (Ghibănescu, XV, p. 156). In fact, the donation in favour of the Monastery Lipovăț proves to be, in the same document, older, from Miron Barnovschi in the year 1628, fact is that year the differentiation between the hydronyms Vaslui and Vasluieț wasn't documented yet, the object of Barnovschi's donation being „a mill in the water of Vaslui” (Ghibănescu, XV, p. 158).

With the inquiry of this dispute going on, we have new elements provided by the memory of the community which seems to preserve in a miraculous way the remembrance of that event passed a couple of centuries ago, when the town of Vaslui was one of the residences owned by Ștefan the Great, with the status of royal town.

"Asking the people since when the watercourse of Vaslui had been diverted from its old bed so that it is now flowing beneath the town, and the people confessed [...] that the water was diverted during the days of Ștefan the Old by digging hendichi ${ }^{27}[\ldots]$ and it was directed beneath the town where there is now the course of Vaslui" (Ghibănescu, XV, p. 158).

The event seems to be credible, but it cannot be connected to the existence, upstream this deviation, of a royal dam, probably where there is nowadays the village Moara Domnească 'Royal Mill':

"[People] gave testimony that the old town was lying in the past from the royal buildings upwards the plateau until the royal dam being only house places" (Ghibănescu, XV, p. 158).

The modern event, from the time of Clementie, is further connected to the one from the time of Ștefan:

"At the end of the milldam of Clementie where there is the breaking of the royal dam from where the water was diverted, because there were some logs" (Ghibănescu, XV, p. 158).

For its subtlety we mention also the solution for this dispute regarding the location of the mill ford received as a donation by the Monastery Lipovăt from Miron Barnovschi, solution suggested in the document through an exercise of logic:

\footnotetext{
${ }^{27}$ From Turkish hendek 'ditch of defense, rampart, ditch'; was it a ditch made by Ștefan the Great in order to defend the town, in association with the deviation of the river Vaslui?
} 
"If someone would want to make a mill in the backwater named Old Vaslueț, he may do it, but it will be running only with the river Vaslui flooding, or else it would remain dry, as it is now this channel dried" (Ghibănescu, XV, p. 158).

Returning to the main information about the hydronymic pair Vaslui / Vasluieț, we refresh that piece of information given by Ghibănescu concerning the plan of the town Vaslui, dated in the same year 1783: "The Old Vaslui was flowing more eastwards toward the Hill Bustea ${ }^{28}$, while the New Vaslui is flowing beneath the Town Hill” (XV, p. 158).

In HARTA MIL. it is marked upwards of the village Moara Domnească a deviation of the brook Vaslui, a parallel crotch eastwards of the main watercourse, yet this is regaining the main course also upwards of Moara Grecilor.

Again at 1725 the description of the limits of the village Tătărași towards Vaslui confirms what we can see some decades later in the plan of the town from 1783: „beyond the plain towards East over the watercourse of Vaslui, on the Old Vaslui until the origin of topile ${ }^{\ddagger}[. .$.$] and thence along a little road over$ the Valley of Bustea" (Ghibănescu, XV, p. 131).

The existence of the royal dam upwards of the town could be linked to the existence of a royal mill upstream the town (see the present village Moara Domnească), however it can explain less the diversion of the river Vaslui in front of the town Vaslui, that is downwards the mill area (Moara Domnească, Moara Grecilor). In order to fulfill its function, i.e. feeding the dam of a mill, the diversion of a running water has to be done upstream of the mill and, obviously, of the millpool. The activity of river regulation that seems to have been undertaken during the reign of Ștefan the Great might have had different reasons, in addition one must take into account also the fact that in the mouth area, the river Vaslui has and, probably, had an irregular course, on account of the morphology of the terrain.

3.3. Similar situations, out of similar causality, seem to be offered by the occurence of the denomination Old Vaslui or Former Vaslui in other sections of the brook too, namely in its superior course, therefore with no connection to what has happened in its inferior course. Thus in 1644 postelnicul 'great Boyar' Grigorie is buying "the whole village Ruseni, from the same district [Vaslui] [...] but with half a mill ford, and with the mill already, and with the fourth < part> of Poiana Cîrnului and with the beech forest, starting from the property of Șerbești downwards until [blank], and in the plain where the Old Vaslui was" (DRH, A, XXVIII, p. 386). We do not think we would have here already the extension of the concurrent name of the primitive hydronym Vaslui (Old Vaslui as a synonym for Vasluiet,), but only the designation of a part of the rivercourse representing its old riverbed, dried up through the diversion of the course as a result of anthropical or natural causes.

Therefore we might have a multiple cause, one could say, of the substitution of the old hydronym Vaslui by its diminutival form Vasluieț.

\section{Comparison to other types of hydronymic differentiation}

This type of differentiation has been explained by Dragoș Moldovanu (2014; see supra) with reference to the case of the toponymic field of Corod, who analysed the evolution of the relationship between the locality Corod and the brook Corozel on which the former is presently situated.

4.1. Our contribution is meant to bring up some specific information regarding the distinction between this type of toponymic differentiation and the type examined by us. While the relative homonymy with the oikonym Vaslui is to be admitted as a cause, in our case also a secondary one, of the extension of the diminutival form Vasluieț in preference to the normal form Vaslui of the hydronym, which is older, the initial cause seems to be different here; within this field the primary opposition Vaslui vs Vasluieț refers

\footnotetext{
${ }^{28}$ On the Easter side of this hill there is the village Băhnarii situated eastwards of the town of Vaslui (MDG, II, 85/3).

${ }^{\ddagger}$ Pool in a lake or in a running water to rot the hemp.
} 
only to the springs area of the brook, thence it is unlikely an extension of the name of a constituent branch over the whole watercourse. Besides, we documented the existence of the other primary opposition, from the inferior course of the river, [Old] Vaslui vs New Vaslui, subsequently Vasluieț vs Vaslui. For the right apprehension of the denominative variants Vasluiet, Old Vaslui, Old Vasluieț used to designate the old waterbed of Vaslui, see our comment regarding Tecucel, Tecucelul Sec, Tecuciul Sec in Cojocaru (2015).

4.2. One last question would refer to the impact that a change of the physico-geographical features of the reference could have at the level of toponymic denomination. How quickly can a physico-geographical change be reflected in the toponymic inventory of a zone? The supposed event from the time of Ștefan the Great seems to have been reflected at toponymic level only after a couple of centuries.

\section{Conclusions}

5.1. We called it atypical differentiation, because it is different from the typologies analysed so far:

a. It is not an extension of a diminutival form of the hydronym from the main tributary over the main watercourse (in stages or not: hydronym ${ }^{*}$ Corod vs hydronym Corozel; hydronym ${ }^{*}$ Tecuci vs hydronym Tecuce $\left.{ }^{29}\right)$.

b. It is not either about the preservation of the diminutival form of the hydronym by the secondary tributary followed by the disappearance - in fact by the substitution - of the basic form of the name designating the main watercourse ( ${ }^{*} B \hat{r} r z a v a \rightarrow U z u l$ vs Bîrzăuţa ${ }^{30}$ ) or, more complicated, accompanied by the reappearance of the basic denomination at the secondary tributary $\left({ }^{+}\right.$Sagna $\rightarrow$ Vulpăşsşti vs Sagna, former ${ }^{+}$Săgnița ${ }^{31}$ ), a phenomenon intermediated by the existence of the locality with the homonymous name situated at the junction of the two watercourses.

c. Therefore, it is about an extension too, like in the case a., but not the extension of the name of a tributary, be it main or not main, in fact an extension of the name of a deviation representing the old watercourse of the river. We specify again that in all these types of hydronymic extension the oikonym from the field, i.e. the name of the locality could have been a contributory factor, due to the homonymy between this one and the hydronym (Moldovanu, 2014, p. XII), and in the case of the field Sagna from b. the presence of the oikonym being even a condition sine qua non of the process.

5.2. As it can be noticed from our argumentation, in none of the types of toponymic differentiation mentioned above was brought into question the presence of a suffix having exclusively a toponymic function, on the contrary, in this process more suffixes have been implied which are used in commun lexis: $-e t$, but also $-e l,-i t ̦ a$. On the other hand, we didn't consider pertinent the analogy with the form pruteț '[any] channel or pool [?] of the river Prut', because the situation of the toponymic field of the hydronym Vaslui is different from the one of the river Prut. In the first case, the diminutival form, Vasluiet, is documented with its function to designate a constituent brook of the main course, thence situated in the springs zone, and not any branch of Vaslui. In reply, we don't know any tributary of the river Prut, constituent-that is, in the springs area-or not, to be called Prutet, except for the sectors of the former course or of the pools created by the flood of Prut. An eventual analogy with the situation of prutețe would be acceptable only for the mouth zone of Vaslui, where the course of the river branches out in an older and a newer one. Nevertheless even in this area the phenomenon is different, because the documents seem to attest human handling in an effort of regularization of the watercourse, in other words an anthropical cause.

\footnotetext{
${ }^{29}$ A more complex evolution we can find in the case of the pair Voitin / Voitinel, the two components of the field having the quality both of a hydronym and of an oikonym, see MDTM, I, s.v.

${ }^{30}$ For ,the methodological principle of the reconstruction of some nonattested hydronyms starting from their diminutives which are designating some tributaries", see Moldovanu (2010, p. 27-28), who takes into consideration also the hydronymic pair *Bîrzava vs Bîrzăuța.

${ }^{31}$ For the discussion of this problem, see Cojocaru (2015, p. 76-78).
} 


\section{Bibliography}

ATlas MOLD. = Atlasul Moldovei (1:50 000), Institutul Geografic al Armatei, București, 1892-1898.

Cojocaru, V. (2015). Micul dicționar toponimic al Moldovei, structural și etimologic și cerințele teoriei cîmpurilor toponimice, in "Anuar de lingvistică și istorie literară”, LV, p. 73-80.

DRH, A = Documenta Romania Historica. A. Moldova, I-XXVII, București, 1975-2006.

Ghibănescu, Gh. (1906-1933). Surete și izvoade, vol. I-XXV, Tipografia Dacia, Iași.

Gugiuman et al. (1988). Dicționar geografic al județului Vaslui, I. Gugiuman, V. Cîrcotă, V. Baican, Iași.

HARTA MIL. = Harta R. S. România, executată de Direcția Topografică Militară, (1:25 000), București, 1962.

MDG = Marele dicționar geografic al României, I-V, București, 1898-1902.

mDtm, I = Mic dicționar toponimic al Moldovei, structural și etimologic. Partea I. Toponime personale (coordonator: Dragoș Moldovanu), Editura Universității „Alexandru Ioan Cuza”, Iași, 2014.

Moldovanu, D. (2010). Teoria cîmpurilor toponimice (cu aplicație la câmpul hidronimului Moldova), Editura Universității „Alexandru Ioan Cuza”, Iași, 2010.

Moldovanu, D. (2014). Introduction to MDTM, I.

NALR-DATE = Noul Atlas Lingvistic al României. Moldova și Bucovina. Date despre localități și informatori, Editura Academiei, București, 1987.

Roм. = România. Atlas rutier, de general maior ing. Vasile Dragomir, col. ing. Victor Balea, col. ing. Gheorghe Mureșanu, Gheorghe Epuran, sc. 1:350 000, București, 1981.

TTRM = Tezaurul toponimic al României. Moldova (coordonator: Dragoș Moldovanu). $\mathrm{I}_{1-2}$, Repertoriul istoric al unităților administrativ-teritoriale (1772-1988), București, 1991-1992. $\mathrm{I}_{3}$, Toponimia Moldovei în documente scrise în limbi străine (exclusiv slavona), Iași, 2004. $\mathrm{I}_{4}$, Toponimia Moldovei în cartografia europeană veche (cca 1395-1789), Iași, 2005. 